\title{
JĖGOS DEPRESIJOS PRIKLAUSOMYBE் NUO RAUMENS STIMULIACIJOS DAŽNIO IR ATLIKTO DARBO
}

\author{
Gintarė Dargevičiūtė, Nerijus Masiulis, Albertas Skurvydas, Sigitas Kamandulis, \\ Edita Kavaliauskienė, Zita Andrijauskaitė, Dovilè Parulytė, Vaida Aleknavičiūtė \\ Lietuvos kūno kultūros akademija, Kaunas, Lietuva
}

Gintarẻ Dargevičiūtė. Biomedicinos mokslų magistrè. Lietuvos kūno kultūros akademijos biomedicinos mokslų krypties doktorantė. Mokslinių tyrimų kryptis — griaučių raumenų greitoji adaptacija.

\section{SANTRAUKA}

Raumens susitraukimo jëga, užregistruota tuojau po aktyvaus raumens susitraukimo, yra mažesnè už jëga, užregistruota izometrinio susitraukimo metu (lyginama esant tokiam pat raumens ilgiui) (Abbott, Aubert, 1952; Sugi, Tsuchiya, 1988; Edman et al., 1993; Herzog, 1998; De Ruiter et al., 1998; Kosterina et al., 2008; Rode et al., 2009; Tilp et al., 2009). Toks reiškinys vadinamas po raumens susitraukimo atsiradęs jègos sumažejimas arba jègos depresija (JD) (Abbott, Aubert, 1952; Herzog, 1998; De Ruiter et al., 1998). Raumenujégos sumažejimas po raumens susitraukimo yra didesnis, kai raumuo susitraukia didesne jèga (De Ruiter et al., 1998), didesne amplitude (Herzog, 1998; De Ruiter et al., 1998), mažesniu greičiu (De Ruiter et al., 1998; Herzog et al., 2003) ir susitraukdamas atlieka didesni darba (Herzog, 1998; Herzog et al., 2000).

Dar nèra žinoma, kaip JD priklauso nuo raumenu nuovargio, treniruotumo, raumenu atrofijos ar raumenu ligu. Todèl manytume: norint geriau suprasti griauči raumenu funkcija svarbu nustatyti, ar raumenu nuovargis gali paveikti $J D$.

Tyrimo tikslas — nustatyti, ar skirtingais elektrostimuliacijos dažniais valingai aktyvavus keturgalvĭ šlaunies raumeni nuovargis veikia po raumens sutrumpejjimo atsiradusia JD. Sveiki nesportuojantys vyrai $(n=8)$ atliko izometri$n i$-koncertini-izometrini (Izom-Kon-Izom) ir izometrini raumens susitraukima (IZO), stimuliuojant keturgalvi šlaunies raumeni $20 \mathrm{~Hz}, 50 \mathrm{~Hz}$ dažnio stimulu ir išugdant maksimaliajq valingajèga (MVJ). Norint sukelti raumenu nuovargi buvo atliekamas ekscentrinis krūvis - 10 seriju po 10 kartojimu (kojos tiesimo amplitude - nuo $110^{\circ}$ iki $60^{\circ}$ kampo per kelio sqnari). Izokinetinis dinamometras neleido išlaikyti ištiestos kojos ir lenkè ja $120^{\circ} / \mathrm{s}$ greičiu. Kreatinkinazès (CK) aktyvumas kraujo serume buvo vertinamas prieš krūvi ir praejus 48 h po jo.

Raumenu JD, stimuliuojant keturgalvi šlaunies raumeni mažais dažniais, po krūvio reikšmingai padidejja vèlesnèje atsigavimo fazèje $(p<0,05)$. Raumenu pažeidq sukeliantis ekscentrinis krūvis neveikia JD, kuomet keturgalvis šlaunies raumuo stimuliuojamas dideliais dažniais ar kai raumenujèga išugdoma didžiausiomis valios pastangomis.

Raktažodžiai: jëgos depresija, elektrostimuliacija, raumenu pažeida, nuovargis.

\section{IVADAS}

$\mathrm{S}$ usitraukimo jèga, užregistruota nedelsiant po aktyvaus raumens susitraukimo, yra mažesnè negu jẻga, užregistruota izometrinio susitraukimo metu (lyginama esant tokiam pat raumens ilgiui). Toks reiškinys vadinamas po raumens susitraukimo atsiradęs jègos sumažejjimas arba jègos depresija (JD).

A. F. Huxley ir R. Niedergerke 1954 m. pasiūlytos raumens susitraukimo slenkančių siūlų (filamentu) teorijos arba A. V. Hill 1938 m. miozino ir aktino skersiniu tiltelių teorijos nepakanka norint paaiškinti daugybę griaučių raumenu tyrimo rezultatú. Pavyzdžiui, tiriant visą raumeni ar ląstelę buvo įrodyta, kad ši teorija nepaaiškina raumenu jègos pokyčio, atsirandančio iškart po raumens ištempimo arba susitraukimo (Rode et al., 2009). Daugelis mokslininkų nustate, kad raumens susitraukimo jèga, užregistruota nedelsiant 
po aktyvaus raumens susitraukimo yra mažesnè už jègą, užregistruotą izometrinio susitraukimo metu (lyginama esant tokiam pat raumens ilgiui) (Abbott, Aubert, 1952; Herzog, 1998). Toks reiškinys vadinamas po raumens susitraukimo atsiradęs jègos sumažèjimas arba JD (De Ruiter et al., 1998).

Šis raumenu susitraukimo fenomenas retai aptariamas, kai kalbama apie raumenu jègą lemiančius veiksnius (Herzog, 1998). Toks ignoravimas yra stulbinantis, nes JD po raumens susitraukimo gali siekti net 38\% (De Ruiter et al., 1998). Pasak W. Herzog (1998), raumenų JD ignoravimas gali būti susijęs su tuo, kad šis fenomenas sunkiai paaiškinamas tradicine miozino ir aktino skersiniu tilteliu teorija (Huxley, 1957) ar A. V. Hill modeliu (Hill, 1938), neaiškūs ir patys JD mechanizmai.

Visgi keletas mechanizmų gali paaiškinti po aktyvaus raumens susitraukimo atsiradusi jègos sumažejjimą: 1) sarkomerų heterogeniškumas (sarkomeru ilgio nevienodumas), padideję̨s po raumens susitraukimo; 2) sumažejęs $\mathrm{Ca}^{2+}$ išmetimas iš sarkoplazminio tinklo iškart po raumens susitraukimo (Edman, 1996); 3) padidejusi protonu ir neorganinio fosfato koncentracija iškart po raumens susitraukimo (Granzier, Pollack, 1989); 4) mechaninis stresas aktino ir miozino sukibimo zonoje, atsirandantis koncentrinio susitraukimo metu (Maréchal, Plaghki, 1979); 5) susitraukimo metu atsiranda miozino molekulę prie aktino prijungiančiu laisvų vietų, prie kuriu prisijungia titinas, smarkiai sumažindamas ląstelès ilgi (Rode et al., 2009). Visgi nè vienas iš ju negali paaiškinti visų tyrimo metu gautų rezultatu (Rassier, Herzog, 2004).

Tarp atlikto darbo (raumens susitraukimo metu) ir JD yra stiprus koreliacinis ryšys (Herzog et al., 2000). Nuovargio metu raumuo atlieka mažesni darbą, tad keliame hipotezę: nuovargio metu sumažejus atliktam darbui, sumažès ir JD.

N. Masiulis ir kt. (2009) nustatė JD priklausomybę nuo raumenų nuovargio stimuliuojant keturgalvi šlaunies raumeni $50 \mathrm{~Hz}$ dažniu, tačiau nèra žinoma, kaip JD priklauso nuo raumenu nuovargio, stimuliuojant keturgalvị šlaunies raumeni skirtingais stimuliacijos dažniais ir išugdant MVJ.

Tyrimo tikslas - nustatyti, ar skirtingais elektrostimuliacijos dažniais valingai aktyvavus keturgalvi šlaunies raumeni nuovargis veikia po raumens sutrumpejjimo atsiradusią JD.

\section{TYRIMO METODIKA}

Tiriamieji. Buvo tiriami 8 nesportuojantys sveiki vyrai, neturèję kelio sąnario traumų. Jų amžius $21,9 \pm 2,6 \mathrm{~m}$., ūgis $177 \pm 1,5 \mathrm{~cm}$, kūno masè $77,1 \pm 2,7 \mathrm{~kg}$. Tiriamieji buvo supažindinti su tyrimo eiga, tikslais ir galimais nepatogumais. Tyrimas atliktas laikantis 1975 m. Helsinkio deklaracijoje priimtų principų dèl eksperimentų su žmonèmis etikos.

Dinamometrija. Izometrinè blauzdos tiesiamuju raumenu jèga buvo vertinta naudojant izokinetini dinamometrą (Biodex Medical System 3, New York). Prie dinamometro pritvirtinamas papildomas blauzdos tvirtinimo itaisas. Kelio anatominè sąnario ašis nustatoma ir sulyginama su dinamometro dinaminès apkrovos mazgo ašimi. Nustatoma kelio sąnario amplitudè (ištiesus koją $0^{\circ}$ ir sulenkus $110^{\circ} \mathrm{kampu}$ ). Mažinant viso kūno inercini svyravimą, tiriamieji buvo apjuosiami pečių, liemens ir šlaunies diržais. Blauzda įtvirtinama diržu virš kulnakaulio gumburo ties apatiniu trečdaliu, pasveriama tada, kai ji fiksuota $60^{\circ}$ kampu (veikia sunkio jèga) (1 pav.).

Elektrostimuliacija. Taikant tiesioginę elektrostimuliaciją, ant keturgalvio šlaunies raumens tolimojo ir artimojo trečdalių dedami elektrodai elektrai laidžios gumos (suteptos geliu). Elektrodai sujungti su elektrostimuliatoriumi, imontuotu i elektromiografą Medicor MG440. Raumuo jaudinamas stačiakampès formos elektriniu impulsu arba jų serija. Vienkartinio impulso trukmė $1 \mathrm{~ms}$, itampa parinkta tokia, kad sukeltų didžiausią raumens susitraukimo jègą $(150 \mathrm{~V})$ (Masiulis et al., 2009). Keturgalvis šlaunies raumuo buvo aktyvuojamas 20 ir $50 \mathrm{~Hz}$ dažnio impulsų serijomis. Jègos depresijos registravimo metu raumeni stimuliuojant 20 ir $50 \mathrm{~Hz}$ dažniu, stimuliacija truko $10 \mathrm{~s}$. Elektrostimuliatoriaus siunčiami impulsai registruojami Biodex Medical System kompiuteriu.

Jègos depresijos (JD) registravimas. Elektrostimuliacijos sukelta JD registruota stimuliuojant keturgalvi šlaunies raumeni $20 \mathrm{~Hz}$ dažniu $10 \mathrm{~s}$ (JD 20) izometrinio - koncentrinio-izometrinio (Izom-Kon-Izom) susitraukimo metu (1a pav). Nenutrūkstamas 10 s Izom-Kon-Izom susitraukimas buvo atliktas, kai keturgalvis šlaunies raumuo stimuliuojamas $3 \mathrm{~s}$ sulenkus koją $110^{\circ} \mathrm{kampu}$, vèliau atliekamas nenutrūkstamas $3 \mathrm{~s}$ koncentrinis susitraukimas, kurio metu tiriamojo koja per kelio sąnari buvo tiesiama nuo $110^{\circ}$ iki $60^{\circ}$ kampo (koja tiesiama $30^{\circ} / \mathrm{s}$ greičiu), o koją ištiesus iki $60^{\circ}$ kampo stimuliacija tęsiama dar $4 \mathrm{~s}$ (1a pav.). 
1 pav. Kojos padètis tyrimo metu

Pastaba. Koja ištiesta per kelio sąnarị $0^{\circ}$. A) Izom-Kon-Izom — izomerinis, koncentrinis, izometrinis susitraukimas, B) IZO izometrinis susitraukimas.

2 pav. Jègos-laiko (A) ir kampo-laiko (B) kitimas registruojant vieno iš tiriamųjų IZO ir Izom-Kon-Izom raumens susitraukimą

Pastaba. 1 linija - IZO susitraukimas; 2 linija - Izom-Kon-Izom susitraukimas. Skirtumas tarp IZO ir Izom-Kon-Izom susitraukimu yra vadinamas jègos depresija (JD). 1 ir 2 kreivių reikšmès buvo analizuojamos $8-9 \mathrm{~s}$.
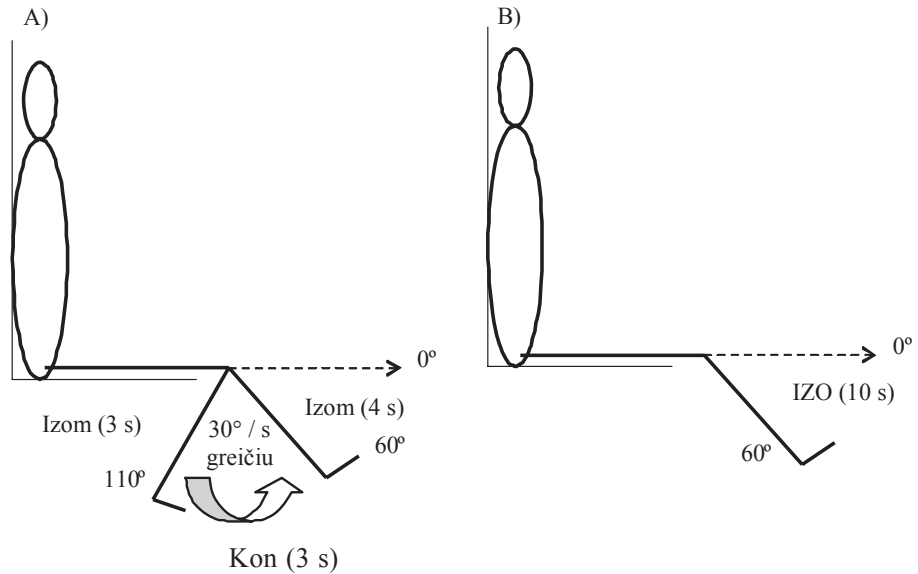

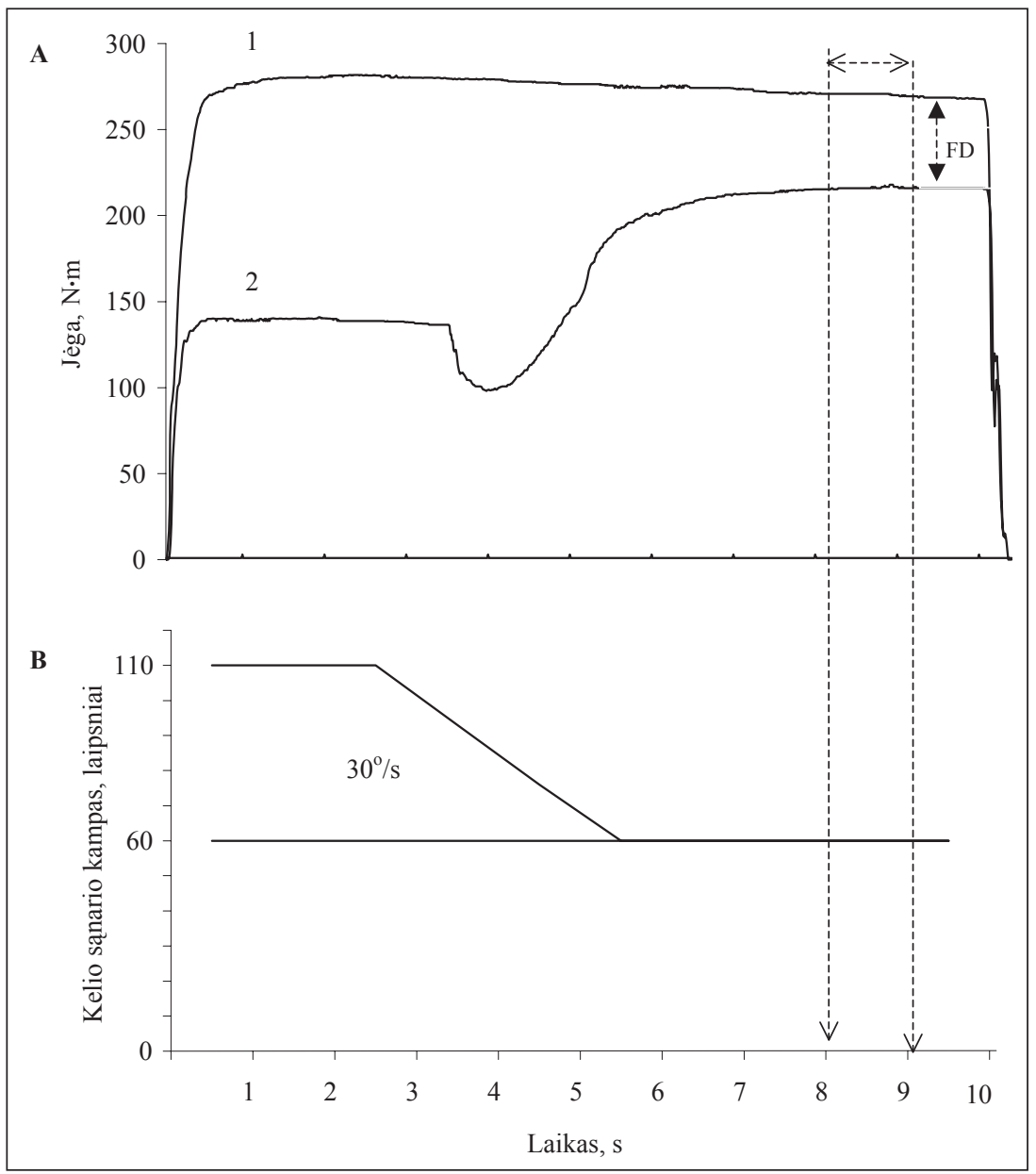

Po Izom-Kon-Izom elektrostimuliacija sukelto raumens susitraukimo buvo atliekamas tik izometrinis (IZO) elektrostimuliacija sukeltas raumens susitraukimas ( $1 \mathrm{~b}$ pav). Izometrinio susitraukimo metu keturgalvis šlaunies raumuo buvo stimuliuojamas P 20 dažniu 10 s, kai koja per kelio sąnari sulenkta $60^{\circ} \mathrm{kampu}$. Po JD 20 registravimo buvo nustatoma JD stimuliuojant keturgalvi raumeni $50 \mathrm{~Hz}$ dažniu (JD 50) ir JD, išugdant maksimaliają valingą jègą (JD MVJ). Originalios vieno tiriamojo Izom-Kon-Izom ir IZO kreivès pateiktos 2 paveiksle.

Tyrimo protokolas. Tiriamieji atliko $5 \mathrm{~min}$ pramankštą veloergometru (80-90 aps. / min, $70-80 \mathrm{~W}$ ). Praejjus $5 \mathrm{~min}$ po pramankštos, raumuo buvo stimuliuojamas 20 (P 20) ir 50 Hz (P 50) dažniu. Stimuliavimo trukmè 1 s. Poilsio trukmé tarp stimulu 3 s. Praejus 1 min po elektrostimuliacijos 
buvo nustatoma maksimalioji valinga jèga (MVJ). Tiriamieji atliko 2 bandymus kas 1 min. Praejus 5 min po šių matavimų, buvo registruojama JD 20 (1 a pav.). Po Izom-Kon-Izom elektrostimuliacija sukelto raumens susitraukimo buvo atliekamas tik izometrinis (IZO) elektrostimuliacija sukeltas raumens susitraukimas ( $1 \mathrm{~b}$ pav.). Poilsio intervalas tarp Izom-Kon-Izom ir IZO susitraukimu 3 minutės. Praejjus 5 min po JD 20 registravimo, registruota JD 50, o praejus 5 min po JD 50 - JD MVJ.

Krūvis. Ekscentrinio krūvio metu tiriamieji turejo tiesti koją (tiesimo amplitudè - nuo $110^{\circ}$ iki $60^{\circ}$ kampo per kelio sąnari), o izokinetinis dinamometras Biodex Medical System neleido išlaikyti ištiestos kojos ir lenkè ją $120^{\circ} / \mathrm{s}$ greičiu. Taigi keturgalvis šlaunies raumuo dirbo ekscentriniu režimu. Tiriamieji atliko 10 serijų po 10 kartojimu. Poilsio intervalas tarp kiekvienos serijos 2 minutès. Praejjus 5 ir 60 min po krūvio buvo registruojama 20 ir $50 \mathrm{~Hz}$ jèga. Po elektrostimuliacijos buvo registruojama MVJ (atliekami du
MVJ bandymai kas $1 \mathrm{~min}$ ), praejjus 5 min po MVJ buvo registruojama JD 20, JD 50 ir JD MVJ.

Kreatinkinazès (CK) kraujo serume nustatymas. CK aktyvumas kraujo serume buvo vertinamas prieš krūvị ir praejjus $48 \mathrm{~h}$ po jo. Norint ivertinti CK aktyvumą kraujo serume, iš tiriamuju rankos venos buvo imamas kraujas (apie $5 \mathrm{ml}$ ). Analizè atlikta prieš tyrimą ir praèjus $48 \mathrm{~h}$ po krūvio. Méginio analizavimo procedūra atlikta Lietuvos kūno kultūros akademijoje automatiniu biocheminiu analizatoriumi SPOTCHEM EZ SP4430 (gamintojas ARKRAY, Japonija).

Matematine statistika. Tyrimo rezultatai apdoroti matematinès statistikos metodais, skaičiuojant aritmetini vidurki ( $\bar{x})$, standartini nuokrypi (S) ir vidurkiu skirtumo patikimuma. Porinių rezultatu skirtumas tarp grupių vertintas Stjudento t (Student $t$ ) kriterijumi. Remiantis dvieju veiksniu dispersine analize, skirtumas laikomas reikšmingu, kai $\mathrm{p}<0,05$. Skaičiavimai atlikti naudojantis Microsoft Excel 2003 ir SPSS13 programomis.
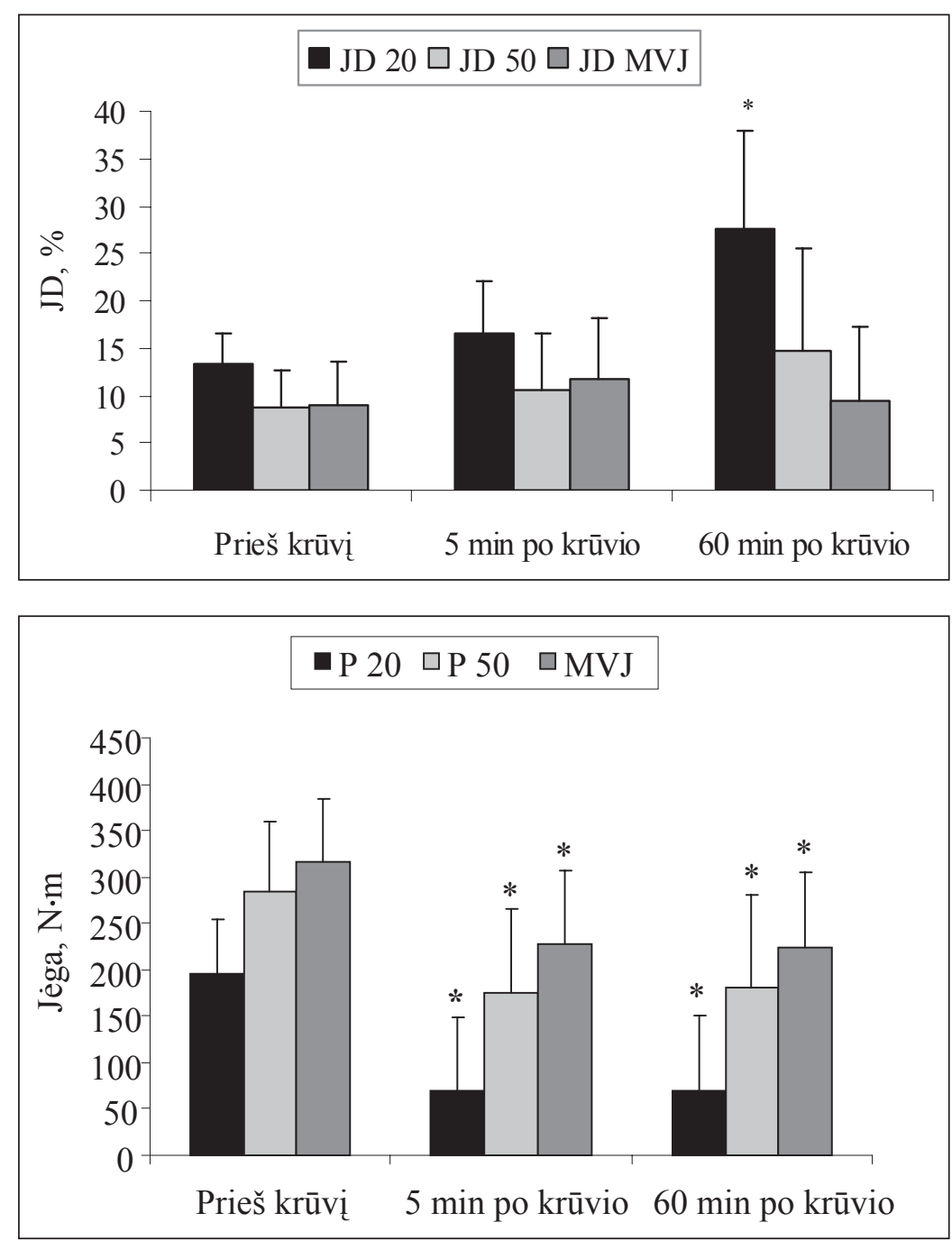

3 pav. JD 20, JD 50 ir JD MVJ kitimas prieš krūvį ir praèjus 5,60 min po jo

Pastaba. $*-p<0,05$, palyginti su reikšme prieš krūvị; \#- p $<0,05$, palyginti su JD 20 reikšme.

4 pav. Keturgalvio šlaunies raumens susitraukimo jègos P 20, P 50 ir MVJ reikšmių kitimas prieš krūvį ir praėjus 5,60 min po jo

Pastaba. * $-p<0,05$, palyginti su reikšme prieš krūvị. 
5 pav. Atlikto darbo ir JD 20, JD 50 ir JD MVJ kitimas prieš krūvị ir praèjus 5 , 60 min po jo
Pastaba. * $-\mathrm{p}<0,05$, palyginti su reikšme prieš krūvị.

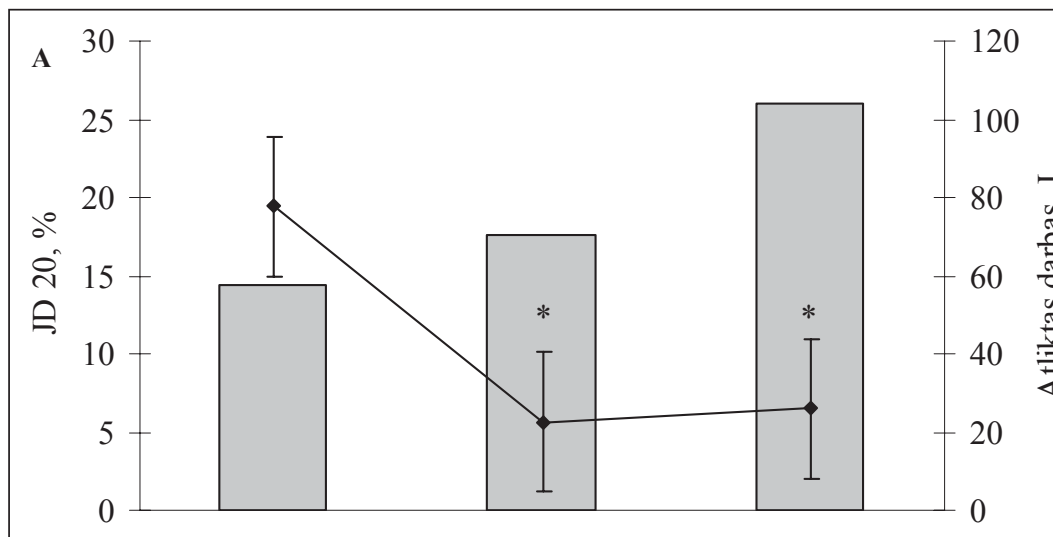

12

B

10

$\begin{array}{ll}\text { ㅇ } & \\ 0 & \\ 0 & \end{array}$

ค 6

4

2

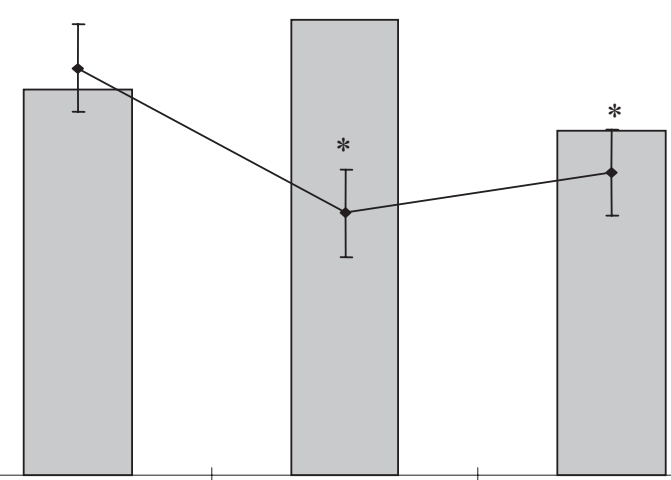

120

100

80

60

40

20

0

$\begin{array}{ll}0 & 0 \\ 9 & 160\end{array}$

C
$\quad 8$

$+5$

140

140

120

$\begin{array}{ll}\sum^{\circ} & 6 \\ 5 & \end{array}$

$\ominus 4$

3

2

1

0

\section{REZULTATAI}

Analizuojant JD 20 reikšmes matyti (3 pav.), kad praejjus 60 min po krūvio JD 20 padidèjo statistiškai reikšmingai $(p<0,05)$, o tarp JD 50 ir JD MVJ rodiklių reikšmingo skirtumo nenustatyta $(\mathrm{p}>0,05)$. Praejus 5 ir 60 min po krūvio, dvieju tiriamujų JD MVJ nepasireiškè.

Nagrinejjant P 20, P 50 ir MVJ reikšmes matyti (4 pav.), kad praejjus 5 ir 60 min po krūvio visi registruoti jègos rodikliai sumažèjo statistiškai reikšmingai $(\mathrm{p}<0,05)$.

Atlikto darbo ir JD 20, JD 50 reikšmès, praèjus 5 ir 60 min po krūvio, statistiškai reikšmingai sumažèjo ( $\mathrm{p}<0,05)(5 \mathrm{a}, 5 \mathrm{~b}$ pav.), o koreliacinis JD 20, JD 50 ir atlikto darbo ryšys buvo toks: JD $20-0,71 ; 0,42 ;-0,30$, JD $50--0,68 ;-0,48$; 0,19 atitinkamai prieš krūvị ir praejjus 5 ir $60 \mathrm{~min}$ po jo.

Analizuojant JD MVJ ir atlikto darbo reikšmes matyti (5 C pav.), kad praejus 5 min po krūvio atlikto darbo reikšmės statistiškai reikšmingai sumažèjo $(p<0,05)$, tačiau mažèjant JD MVJ mažeja ir atliktas darbas (5 C pav.), o koreliacinis ryšys nèra stiprus: $-0,65 ;-0,74 ; 0,29$ atitinkamai prieš krūvi, praèjus 5 ir 60 min po jo.

Kreatinkinazès (CK) koncentracija kraujo serume prieš ekscentrinị krūvị $-2,41$ mikrokatai- 
lu / 1, o praèjus 48 h po jo padidèjo iki 8,05 mikrokatailų / 1. CK reikšmès statistiškai reikšmingai padidejo praejjus $48 \mathrm{~h}$ po krūvio $(\mathrm{p}<0,05)$. Praejjus $48 \mathrm{~h}$ po krūvio tiriamieji jaute vidutini raumenu skausmą $(5 \pm 1,6$ balo).

\section{REZULTATUQ APTARIMAS}

Tyrimo rezultatai parodè, kad po aktyvaus raumens susitraukimo atsiradęs jègos sumažèjimas priklauso nuo raumenų nuovargio tik tuo atveju, kai raumuo stimuliuojamas mažais dažniais. Raumenų pažeidą sukeliantis ekscentrinis krūvis neturi itakos JD, kuomet keturgalvis šlaunies raumuo stimuliuojamas dideliais stimuliacijos dažniais ar kai raumenu jèga išugdoma didžiausiomis valios pastangomis.

Jègos depresija prieš krūvị. Gana netikètas tas rezultatas, kad JD, sukelta stimuliuojant keturgalvi šlaunies raumeni $20 \mathrm{~Hz}$ dažniu, buvo statistiškai reikšmingai didesnè už JD, sukelta stimuliuojant raumenị $50 \mathrm{~Hz}$ dažniu, ir išugdant jẻgą maksimaliomis valios pastangomis (3 pav.). Panašius rezultatus gavo ir W. Herzog (1998), kuris nustate, kad stimuliuojant trumpaji rankos nykščio atitraukiamaji raumeni (adductor pollicis) $10 \mathrm{~Hz}$ JD yra didesnè nei stimuliuojant $30 \mathrm{~Hz}$, tačiau dauguma autoriu gavo priešingą rezultata, t. y. kuo išugdoma jëga yra didesnè (didesnis stimuliacijos dažnis), tuo didesnè JD (pvz., Abbott, Aubert, 1952; De Ruiter et al., 1998).

Mūsų tyrimo metu JD, užregistruota (3 pav.) raumeniui susitraukiant $30^{\circ} / \mathrm{s}$ greičiu (koja sulenkta $110^{\circ}-60^{\circ} \mathrm{kampu}$ ) buvo $14,4,9,6 \%$ ir $7,7 \%$, kai raumuo stimuliuojamas $20,50 \mathrm{~Hz}$ dažniu ir jèga išugdoma didžiausiomis valios pastangomis. H. D. Lee ir kt. (1999) tyrimo rezultatai (autoriai tyrẻ keturgalvi šlaunies raumeni) sutampa su mūsų gautaisiais. Jie nustaté, kad maksimaliosios valingos jëgos depresija, raumeniui susitraukiant $16^{\circ} / \mathrm{s}$ greičiu $60^{\circ}$ amplitude, svyravo nuo 0,7 iki $11,8 \%$. Deja, šio tyrimo metu autoriai netyrè elektrostimuliacija sukeltos JD.

Kitas gana netikètas rezultatas yra tas, kad tarp atlikto darbo (raumens susitraukimo metu) ir JD stipraus koreliacinio ryšio nebuvo nustatyta (5 pav.). W. Herzog ir T. R. Leonard (2000) tyrè katès soleus raumenis šešiais skirtingais protokolais ir visu ju metu nustatė stipru koreliacini ryši tarp atlikto darbo ir JD $\left(r^{2}=0,85\right)$. Kiti autoriai tarp šių rodiklių taip pat pastebejo stiprų ryšį ir JD (De Ruiter et al., 1998; Maréchal, Plaghki, 1979). Jie padare išvadą, kad raumens susitraukimo metu at- liktas darbas yra pagrindinis kintamasis, lemiantis JD dydi (Herzog, Leonard, 2000).

Raumenų nuovargis. Šio tyrimo rezultatai neleidžia abejoti, kad ekscentrinis krūvis (10 seriju po 10 kartojimu atliktas $120^{\circ} / \mathrm{s}$ greičiu) sukèlè raumenų pažeidą. Tai patvirtina ilgai trunkantis elektrostimuliacija sukeltos ir valingai išugdytos raumenu jègos atsigavimas po krūvio (5 pav.), padidejęs CK aktyvumas ir raumenų skausmas paejjus $48 \mathrm{~h}$ po krūvio. Tai sutampa su kitų autoriu tyrimo rezultatais, tvirtinančiais, kad po ekscentrinio krūvio izometrinè jèga sumažèja tuoj pat po pratimo, o elektrostimuliacijos sukelta (Masiulis et al., 2009) ir valingai išugdyta (Proske, Morgan, 2001) raumenu jèga atsigauna pamažu.

Kitų autorių tyrimai rodo, kad koja atlikus 40 maksimalių ekscentriniu susitraukimų kelio tiesiamujų raumenų jèga sumažèja 35\%, taip pat sumažeja raumens galingumas, kuris negrižta i pradini lygi per 2 dienas. C. Byrne ir R. G. Eston (2002) tyrimo rezultatai rodo $30-40 \%$ kelio tiesiamuju raumenų jègos sumažejjimą po ekscentrinių susitraukimu (raumuo, nors ir ne visiškai (apie 95\%), atsigauna tik per 7 dienas). Šie rezultatai visiškai sutampa su mūsų gautaisiais: MVJ praejjus $5 \mathrm{~min}$ po krūvio sumažėjo $89,9 \mathrm{~N} \cdot \mathrm{m}(29 \%)$, o praejjus $60 \mathrm{~min}-92,2 \mathrm{~N} \cdot \mathrm{m}(30 \%)$ (4 pav.).

Praejjus 48 h po krūvio užregistruotas kur kas didesnis CK aktyvumas tiriamujų kraujo plazmoje. Raumenų baltymų ištekèjimas ì cirkuliacinę sistemą rodo sarkolemos laidumo padidejimą ir yra susijęs su jos pažeida (Sjodin et al., 1990). Po fizinio krūvio atsiradęs skausmas taip pat susijęs su raumens, jungiamojo audinio pažeida ir po jo atsirandančiu uždegimu (Lieber, Friden, 2002).

Jègos depresija po krūvio. Gana netikèta tai, kad po krūvio registruojant atlikto darbo (raumens susitraukimo metu) ir JD pokyčius stiprus koreliacinis ryšys nebuvo nustatytas ( 5 pav.). O mažais stimuliacijos dažniais sukelta JD statistiškai reikšmingai buvo didesnè nei $50 \mathrm{~Hz}$ ir MVJ metu sukelta JD (3 pav.). Manome, kad krūvio metu galèjo atsirasti mažų dažnių nuovargis ir padidinti mažų stimuliacijos dažnių sukeltą JD. Yra žinoma, kad mažų dažnių nuovargis labiau veikia raumenu jẻgą, sukeltą mažų nei didelių stimuliacijos dažnių (Proske, Morgan, 2001). Tad keliame hipotezę, kad mažǔ dažniu nuovargis gali paveikti JD, sukeltą mažų stimuliacijos dažnių. Tačiau tam nustatyti reikia atlikti tolesnius tyrimus.

Apibendrinant galima teigti, kad po aktyvaus raumens susitraukimo atsiradęs jègos sumažejji- 
mas priklauso nuo raumenu nuovargio tik tada, kai raumuo stimuliuojamas mažais dažniais. Raumens, stimuliuojamo dideliais dažniais, ir tada, kai raumenu jèga išugdoma didžiausiomis valios pastangomis, JD nuo raumenų nuovargio nepriklauso. Nors mums ir nepavyko aptikti stipraus koreliacinio ryšio tarp atlikto darbo (raumens susitraukimo metu) ir JD (ypač nuovargio metu), visgi galime teigti, kad po aktyvaus raumens susitraukimo atsiradęs jègos sumažėjimas, t. y. JD, yra neatskiriama griaučių raumenų savybè. Norint nustatyti, kaip po raumens susitraukimo atsiradusi JD veikia judesius, būtina atlikti tolesnius tyrimus.

\section{IŠVADOS}

Raumenų JD stimuliuojant keturgalvị šlaunies raumeni mažais dažniais yra didesnè $(p<0,05)$ nei didelių stimuliacijos dažnių sukelta ir maksimaliai valingai išugdyta jèga.

Raumenų JD, stimuliuojant keturgalvị šlaunies raumeni mažais dažniais, reikšmingai padidejja vèlesnèje atsigavimo po krūvio fazèje $(\mathrm{p}<0,05)$. Raumenų pažeidą sukeliantis ekscentrinis krūvis neveikia JD, kuomet keturgalvis šlaunies raumuo stimuliuojamas dideliais stimuliacijos dažniais, ir tada, kai raumenu jèga išugdoma didžiausiomis valios pastangomis.

\section{LITERATŪRA}

Abbott, B. C., Aubert, X. M. (1952). The force exerted by active striated muscle during and after change of length. The Journal of Physiology, 117, 77-86.

Byrne, C., Eston, R. G. (2002). Exercise, muscle damage and delayed onset muscle soreness. Medicine and Science in Sports and Exercise, 34, 1003-1008.

Edman, K. A. P. (1996). Fatigue vs. shortening-induced deactivation in striated muscle. Acta Physiologica Scandinavica, 156, 183-192.

Granzier, H. L., Pollack, G. H. (1989). Effect of active preshortening on isometric and isotonic performance of single frog muscle fibres. The Journal of Physiology, 415, $299-327$.

Herzog, W. (1998). History dependence of force production in skeletal muscle: A proposal for mechanism. Journal of Electromyography and Kinesiology, 8 (2), 111-117.

Herzog, W., Leonard, T. R. (2000). The history dependence of force production in mammalian skeletal muscle following stretch-shortening and shortening-stretch cycles. Journal of Biomechanics, 33, 531-542.

Herzog, W., Leonard, T. R., Wu, J. Z. (2000). The relationship between force depression following shortening and mechanical work in skeletal muscle. Journal of Biomechanics, 33, 659-668.

Herzog, W., Schachar, R., Leonard, T. R. (2003). Characterization of the passive component of force enhancement following active stretching of skeletal muscle. The Journal of Experimental Biology, 206, 3635-3643.

Hill, A. V. (1938). The heat of shortening and the dynamic constants of muscle. In Proceedings of the Royal Society London, 136-195.

Huxley, A. F. (1957). Muscle structure and theories of contraction. Progress in Biophysics and Biophysical Chemistry, 255-318.

Huxley, A. F., Niedergerke, R. (1954). Measurement of muscle striations in stretch and contraction. The Journal of Physiology, 124 (2), 46-47.

Kosterina, N., Westerblad, H., Lännergren, J., Eriksson, A. (2008). Muscular force production after concentric contraction. Journal of Biomechanics, 41 (11), 2422-2429.

Lee, H. D., Suter, E., Herzog, W. (1999). Force depres- sion in human quadriceps femoris following voluntary shortening contractions. Journal of Applied Physiology, $87,1651-1655$.

Lieber, R. L., Friden. J. (2002). Morphologic and mechanical basis of delayed-onset muscle soreness. The Journal of the American Academy of Orthopaedic Surgeons, 10, 67-73.

Maréchal, G., Plaghki, L. (1979). The deficit of the isometric tetanic tension redeveloped after a release of frog muscle at a constant velocity. Journal of General Physio$\log y, 73,453-467$.

Masiulis, N., Skurvydas, A., Kamandulis, S. et al. (2009). Shortening-induced force depression in electrically activated human quadriceps femoris following stretch-shortening cycle exercise. Sporto mokslas, 2 (55), 60-67.

Proske, U., Morgan, D. L. (2001). Muscle damage from eccentric exercise: Mechanism, mechanical signs, adaptation and clinical applications. The Journal of Physiology, 537, 333-345.

Rassier, D. E., Herzog, W. (2004). Considerations on the history dependence of muscle contraction. Journal of Applied Physiology, 96, 419-427.

Rode, C., Siebert, T., Blickhan, R. (2009). Titin-induced force enhancement and force depression: A 'sticky-spring' mechanism in muscle contractions? Journal of Theoretical Biology, 259 (2), 350-60.

De Ruiter, C. J., De Haan, A., Jones, D. A., Sargeant, A. J. (1998). Shortening induced force depression in human adductor pollicis muscle. The Journal of Physiology, 507, 583-591.

Sjodin, B., Hellsten, W. Y., Apple, F. (1990). Biochemical mechanisms for oxygen free radical formation during exercise. Sports Medicine, 10, 236-254.

Sugi, H., Tsuchiya, T. (1988). Stiffness changes during enhancement and deficit of isometric force by slow length changes in frog skeletal muscle fibres. The Journal of Physiology, 407, 215-229.

Tilp, M., Steib, S., Herzog, W. (2009). Force-time history effects in voluntary contractions of human tibialis anterior. European Journal of Applied Physiology, 106 (2), $159-166$. 


\title{
FORCE DEPRESSION DEPENDENCY ON ELECTRICAL MUSCLE STIMULATION AND WORK DONE
}

\author{
Gintarẻ Dargevičiūtė, Nerijus Masiulis, Albertas Skurvydas, Sigitas Kamandulis, \\ Edita Kavaliauskienė, Zita Andrijauskaitė, Dovilè Parulytė, Vaida Aleknavičiūtè \\ Lithuanian Academy of Physical Education, Kaunas, Lithuania
}

\begin{abstract}
The steady-state isometric forces produced following active muscle shortening is smaller than the purely isometric forces produced at the corresponding muscle lengths (Abbott, Aubert, 1952; Sugi, Tsuchiya, 1988; Edman et al., 1993; Herzog, 1998; De Ruiter et al., 1998; Kosterina et al., 2008; Rode et al., 2009; Tilp et al., 2009). This phenomenon is referred to as force depression (FD) following active muscle shortening (Abbott, Aubert, 1952; Herzog, 1998; De Ruiter et al., 1998). There is general agreement that FD increases with increasing shortening force (De Ruiter et al., 1998), increasing magnitudes of shortening (Herzog, 1998; De Ruiter et al., 1998), decreases with increasing speeds of shortening (De Ruiter et al., 1998; Herzog, 2003), and increasing mechanical work done by the muscle during shortening (Herzog, 1998; Herzog et al., 2003).

FD has been well documented for electrically evoked contractions, as well for voluntary contractions, but has not been studied yet how FD is dependant on muscular fatigue, muscle atrophy and muscle illnesses. Therefore, seeking to understand muscular function better, we think, that it is of great importance to investigate does FD can be affected by muscular fatigue.

It has been shown that FD is directly related to the mechanical work performed during the shortening phase. Thus, we hypothesize that in fatigued muscle mechanical work performed will be reduced together reducing FD.

The purpose of this study was to investigate the effects of muscle fatigue on shortening-induced FD in electrically activated and voluntary activated human quadriceps muscle. Healthy untrained men $(\mathrm{n}=8)$ performed isometric - concentric-isometric (Isom-Conc-Isom) contractions and isometric reference contractions (ISOM) using $20 \mathrm{~Hz}, 50 \mathrm{~Hz}$ electrical stimulation and maximal voluntary contraction (MVC). For effects of muscle fatigue the subjects did eccentric exercise consisting of 10 sets with 10 repetitions each $\left(110^{\circ}-60^{\circ}\right.$ range of motion, angle velocities $\left.120^{\circ} / \mathrm{s}\right)$. Besides CK activity was determined pre-exercise and $48 \mathrm{~h}$ after eccentric exercise.

Therefore, it was concluded that FD evoked with low stimulation frequencies significantly increased the later in recovery $(p<0.05)$. Muscle damage generating eccentric exercise has no influence on FD when quadriceps muscle is activated with high stimulation frequencies as well as during MVC. Much research will have to be performed before we understand how FD influences everyday life.
\end{abstract}

Keywords: force depression, electrical stimulation, muscle damage, fatigue.

Gauta 2009 m. lapkričio 8 d.

Received on November 8, 2009

Gintarè Dargevičiūtė

Lietuvos kūno kultūros akademija

(Lithuanian Acedemy of Physical Education)

Sporto g. 6, LT-44221 Kaunas

Lietuva (Lithuania)

Tel +37068313910

E-mail g.dargeviciute@lkka.lt 